\title{
Safety Issue Dossier
}

National Cancer Institute

\section{Source}

National Cancer Institute. Safety Issue Dossier. NCI Thesaurus. Code C97105.

A compilation of documents/material about a particular safety issue. 